\title{
HUBUNGAN ANTARA ASUPAN MAKANAN DAN STATUS KESADARAN GIZI KELUARGA DENGAN STATUS GIZI BALITA DI WILAYAH KERJA PUSKESMAS SEWON I, BANTUL
}

\author{
Sari Purwaningrum, Yuniar Wardani \\ Fakultas Kesehatan Masyarakat Universitas Ahmad Dahlan
}

\begin{abstract}
Background: Poor nutritional status of children in Puskesmas Sewon I in 2007 amounted to $0.60 \%$. Family Nutrition Awareness Status in Puskesmas Sewon I was at $47.06 \%$. Average consumption of energy and protein adequacy of children under the minimum requirements is $19.8 \%$ to $9.9 \%$ for energy and protein. Nutritional status is influenced by several factors, either directly or indirectly and purpose of this study was to determine the relationship of nutrition intake and family nutrition awareness status with under five years child nutritional status in Puskesmas Sewon I Bantul Yogyakarta.
\end{abstract}

Method: Design of this research was cross sectional. The sample size of this study was 97 respondents. Sampling method of thestudy was proportional cluster random sampling technique. The variables examined in this research include under five years child nutritional status, nutrition intake, and family nutrition awareness status. The relationship of each variable was seen by using the Chi Square statistical test.

Results: Results showed that of 97 respondents found 39 children $(40.2 \%)$ had one and the nutritional status of 58 children (59.8\%) had normal nutritional status. Bivariate analysis showed a relationship between under five years children nutritional status with food intake $p<0.05(p=0.000)$ and for under five years children nutritional status with family nutrition awareness status $p<0.05(p=0.03)$.

Conclusion: There was a relationship of nutrition intake and family nutrition awareness status with under five years child nutritional status.

Keyword: nutrition intake, family nutrition awareness status, under five years children nutritional status, Puskesmas Sewon I

\section{PENDAHULUAN}

Masalah gizi di Indonesia pada tahun 2003 adalah sebanyak 28,17\% balita mengalami gangguan gizi kurang dan $8,55 \%$ diantaranya adalah gizi buruk ${ }^{1}$. Prevalensi gizi buruk dan gizi kurang pada balita Indonesia di tahun 2007 yang dinilai menggunakan indeks Berat Badan per Tinggi Badan (BB/TB) sebesar 13,6\% ${ }^{2}$. Prevalensi gizi buruk dan gizi kurang pada balita Indonesia di tahun 2010 berdasarkan indeks BB/TB sebesar $13,3 \%^{3}$. Rata-rata kecukupan konsumsi energi dan protein balita di bawah kebutuhan minimal pada tahun 2010 di wilayah Indonesia sebesar 24,7\% untuk energi dan 18,4\% untuk protein, sementara itu di D. I. Yogyakarta sebesar 19,8\% untuk energi dan $9,9 \%$ untuk protein ${ }^{3}$. Persentase status gizi buruk dan gizi kurang pada balita di Yogyakarta berdasarkan indeks BB/TB sebesar $9 \%^{2}$. Persentase tersebut 
mengalami penurunan pada tahun 2010, yaitu 9,1\% berdasarkan indeks BB/TB3. Cakupan gizi buruk di Kabupaten Bantul pada tahun 2007 sebanyak 295 balita $^{4}$.

Puskesmas Sewon I merupakan salah satu dari 27 Puskesmas yang ada di Kabupaten Bantul yang terletak di Desa Timbulharjo, Kecamatan Sewon, Kabupaten Bantul. Luas wilayah kerja terdiri 2 desa yaitu Desa Timbulharjo dan Desa Pendowoharjo yang terbagi atas 32 dusun ${ }^{5}$. Status gizi buruk balita di wilayah kerja Puskesmas Sewon I, Kecamatan Sewon, Kabupaten Bantul, Yogyakarta pada tahun 2007 sebesar 0,60\%, sementara itu, balita dengan status gizi Bawah Garis Merah (BGM) sejumlah 23 anak dari 2.625 balita yang ada atau sekitar $1,14 \%{ }^{6}$. Cakupan KGK di wilayah kerja Puskesmas Sewon I adalah sebesar 47,06\%. Cakupan tersebut masih berada di bawah target minimum Undang-Undang Nomor 25 Tahun 2000 tentang Program Pembangunan Nasional (Propenas) dan Indonesia Sehat 2010 yang menetapkan bahwa $80 \%$ keluarga menjadi Kadarzi ${ }^{7}$. Berdasarkan latar belakang tersebut, sementara di sana belum ada kajian yang mengaitkan hubungan antara asupan makanan dan status Kesadaran Gizi Keluarga (KGK) dengan status gizi balita, maka peneliti tertarik untuk melakukan penelitian mengenai hubungan antara asupan makanan dan status Kesadaran Gizi Keluarga (KGK) dengan status gizi balita di wilayah kerja Puskesmas Sewon I, Bantul, Yogyakarta.

\section{METODE PENELITIAN}

a. Desain, Tempat, dan Waktu

Jenis penelitian ini adalah observasional analitik dengan rancangan penelitian cross sectional. Penelitian ini dilaksanakan pada tanggal 05 - 26 Juni 2012 di wilayah kerja Puskesmas Sewon I, Bantul, Yogyakarta.

b. Populasi dan Sampel

Populasi dari penelitian ini sebesar 2.791 orang. Sampel yang diambil 93 orang ibu yang memiliki anak balita, kemudian ditetapkan kriteria inklusi (ibu yang memiliki anak usia $>6$ bulan sampai 5 tahun yang terdaftar di Posyandu di Wilayah Kerja Puskesmas Sewon I dan bertempat tinggal di wilayah kerja Puskesmas Sewon I) dan kriteria ekslusi (balita sakit infeksi dan balita usia 0-6 bulan). Sampel kemudian diambil secara cluster random sampling dengan jenis proporsional sampling. Kekurangan sampel diantisipasi dengan penambahan $10 \%$ dari jumlah sampel yang ada. Jumlah sampel kemudian menjadi 102 orang dan 5 diantaranya diekslusi, sehingga total sampel yang digunakan adalah 97 orang.

c. Teknik Pengumpulan Data

1) Data Primer

Asupan makanan diukur dengan menggunakan food recall 2x24 jam. Status Kesadaran Gizi Keluarga (KGK) diukur dengan menggunakan check list KGK dan iodine tes. Status gizi balita diukur dengan menggunakan indeks $\mathrm{BB} / \mathrm{TB}$ yang diperoleh dari hasil pengukuran Berat Badan (BB) dan Tinggi Badan (TB). 
2) Data Sekunder

Data sekunder diperoleh dari berbagai pihak terkait yang meliputi: data geografis wilayah kerja Puskesmas Sewon I Bantul Yogyakarta, data laporan kesehatan, dan data jumlah ibu yang memiliki balita usia 0-5 tahun yang berada di wilayah kerja Puskesmas Sewon I, Bantul, Yogyakarta.

d. Pengolahan dan Analisis Data

Data yang telah terkumpul kemudian diolah dan dianalisis dengan menggunakan komputer. Analisis data univariat disajikan dalam bentuk distribusi frekuensi dan persentase dari setiap variabel, untuk menjelaskan atau mendeskripsikan karakteristik setiap variabel penelitian. Analisis data bivariat dijelaskan dengan menggunakan uji Chi-Square pada $\alpha=0,05$ dan interval kepercayaan $95 \%$, yang disajikan dalam bentuk narasi dan tabel distribusi proprosi.

\section{HASIL PENELITIAN DAN PEMBAHASAN}

\section{A. Hasil Penelitian}

a. Gambaran Umum Wilayah Penelitian

Puskesmas Sewon I merupakan salah satu dari 27 Puskesmas yang ada di Kabupaten Bantul yang terletakdi Desa Timbulharjo, Kecamatan Sewon, Kabupaten Bantul, dengan luas wilayah kerja terdiri dari 2 desa, yaitu Desa Timbulharjo dan Desa Pendowoharjo yang terbagi atas 32 dusun dengan 43 Posyandu, dengan batas wilayah kerja5, yaitu:

1) Sebelah utara : Wilayah kerja Puskesmas Sewon II

2) Sebelah timur : Kecamatan Pleret

3) Sebelah selatan : Kecamatan Bantul

4) Sebelah barat : Kecamatan Kasihan

Luas wilayah kerja Puskesmas Sewon I adalah 1475,76 Ha yang terdiri dari Desa Timbulharjo: 777,76 Km2 dan Desa Pendowoharjo: 698 Km2. Kondisi iklim di wilayah kerja adalah termasuk iklim tropis, dengan bentang lahan yang semuanya terdiri atas daratan, suhu rata-rata: 220C - 320C. Jumlah penduduk wilayah kerja Puskesmas Sewon I pada tahun 2010, berdasarkan data monografi desa tercatat sebesar 36.276 jiwa dengan jumlah kepala keluarga (KK) sebesar 14.007. Hasil pemantauan status gizi buruk balita tahun 2010 di 43 Posyandu diperoleh hasil dari 3024 balita yang ada, yang ditimbang sebanyak 1972 balita dan terdapat $16(0,53 \%)$ balita dengan status gizi buruk dan $31(1,57 \%)$ balita dengan status gizi kurang . 
b. Gambaran Sampel Penelitian

Sampel pada penelitian ini adalah ibu yang memiliki anak balita yang terdaftar di Posyandu di wilayah kerja Puskesmas Sewon I, Bantul, Yogyakarta serta memenuhi kriteria inklusi dan ekslusi. Sampel pada penelitian ini berjumlahlah 102 orang, 5 diantaranya diekslusi sehingga sampel menjadi 97 orang, sedangkan populasinya berjumlah 2.791 orang. Responden dalam penelitian ini sebagian besar berumur $\geq 32$ tahun, yaitu 53 orang (54,6\%); berpendidikan tamat SLTA, yaitu 46 orang $(47,4 \%)$; bekerja sebagai IRT (Ibu Rumah Tangga), yaitu 69 orang (71,1\%); berpendapatan $\geq$ UMR (Upah Minimum Regional), yaitu 56 orang $(57,7 \%)$; dan memiliki jumlah keluarga $\leq 4$ atau keluarga kecil, yaitu 57 orang $(58,5 \%)$. Balita dalam penelitian ini sebagian besar menderita ISPA NonPneumonia, yaitu 57 balita $(58,8 \%)$; berjenis kelamin perempuan, yaitu 52 balita $(53,6 \%)$; memiliki berat badan (BB) $<11,5 \mathrm{~kg}$, yaitu 47 balita $(48,5 \%)$; dan tinggi badan (TB) $\geq 85 \mathrm{~cm}$, yaitu 50 balita $(51,5 \%)$. 


\section{Tabel 1. Karakteristik Responden}

\begin{tabular}{|c|c|c|}
\hline & $\mathrm{n}(\%)$ & Mean \\
\hline \multicolumn{3}{|l|}{ Orang Tua } \\
\hline Umur (tahun) & & 32 \\
\hline$<32$ Tahun & $44(45,4)$ & \\
\hline$\geq 32$ Tahun & $53(54,6)$ & \\
\hline \multicolumn{3}{|l|}{ Pendidikan } \\
\hline Tidak Sekolah & $1(1)$ & \\
\hline Tamat SD & $12(12,4)$ & \\
\hline Tamat SLTP & $19(19,6)$ & \\
\hline Tamat SLTA & $4(47,4)$ & \\
\hline D1 & $6(4,1)$ & \\
\hline D3 & $45(5,2)$ & \\
\hline S1 & $10(10,3)$ & \\
\hline \multicolumn{3}{|l|}{ Pekerjaan } \\
\hline Buruh & $6(6,2)$ & \\
\hline IRT (Ibu Rumah Tangga) & $69(71,1)$ & \\
\hline Karyawan Swasta & $6(6,2)$ & \\
\hline Pedagang & $5(5,2)$ & \\
\hline PNS & $3(3,1)$ & \\
\hline Wiraswasta & $8(8,2)$ & \\
\hline Pendapatan (Rp) & & 1.437 .300 \\
\hline < UMR (892.660) & $41(42,3)$ & \\
\hline$\geq$ UMR (892.660) & $56(57,7)$ & \\
\hline Jumlah Keluarga & & 5 \\
\hline Besar $(>4)$ & $40(41,2)$ & \\
\hline Kecil $(\leq 4)$ & $57(58,8)$ & \\
\hline \multicolumn{3}{|l|}{ Balita } \\
\hline \multicolumn{3}{|l|}{ Morbiditas Balita } \\
\hline Alergi & $1(1)$ & \\
\hline ISPA Non-Pneumonia & $57(58,8)$ & \\
\hline Sehat & $39(40,2)$ & \\
\hline \multicolumn{3}{|l|}{ Jenis Kelamin } \\
\hline Laki-laki & $45(46,4)$ & \\
\hline Perempuan & $52(53,6)$ & \\
\hline Berat Badan $(\mathrm{Kg})$ & & 11,7 \\
\hline$<11,5 \mathrm{Kg}$ & $47(48,5)$ & \\
\hline$\geq 11,5 \mathrm{Kg}$ & $50(51,5)$ & \\
\hline Tinggi Badan (cm) & & 84,4 \\
\hline$<85 \mathrm{~cm}$ & $47(48,5)$ & \\
\hline$\geq 85 \mathrm{~cm}$ & $50(51,5)$ & \\
\hline
\end{tabular}

Sumber: Data primer tahun 2012 
c. Analisis Univariat

Hasil analisis univariat memperlihatkan bahwa mayoritas asupan makanan (energi dan protein) anak balita yang terdaftar di Posyandu di wilayah kerja Puskesmas Sewon I, Bantul, Yogyakarta termasuk dalam kriteria cukup, yaitu 84 balita (86,6\%); sebagian besar keluarga responden termasuk dalam kriteria sudah KGK, yaitu 55 keluarga $(56,7 \%)$; dan balita memiliki status gizi normal berdasarkan indeks berat badan (BB) menurut tinggi badan (TB) atau BB/TB, yaitu 58 balita $(59,8 \%)$.

Tabel 2. Distribusi Responden Berdasarkan Asupan Makanan (Energi) pada Anak Balita yang Terdaftar di Posyandu di Wilayah Kerja Puskesmas Sewon I Bantul Yogyakarta

\begin{tabular}{ccccl}
\hline No & Asupan Energi (Kcal) & Jumlah & Persentase (\%) & \multicolumn{1}{c}{ Statistik } \\
\hline 1. & Kurang & 13 & 13,4 & Mean $=976,46$ \\
2. & Cukup & 84 & 86,6 & Median $=941,6$ \\
& Total & 97 & 100 & Modus $=1051$ \\
& & & & Min. $=488,4$ \\
& & & & Maks. $=1621,6$ \\
\hline
\end{tabular}

Sumber: Data primer tahun 2012

Tabel 3. Distribusi Responden Berdasarkan Asupan Makanan (Protein) pada Anak Balita yang Terdaftar di Posyandu di Wilayah Kerja Puskesmas Sewon I Bantul Yogyakarta

\begin{tabular}{lcccl}
\hline No & Asupan Energi (Kcal) & Jumlah & Persentase (\%) & \multicolumn{1}{c}{ Statistik } \\
\hline 1. & Kurang & 13 & 13,4 & Mean $=26,86$ \\
2. & Cukup & 84 & 86,6 & Median $=26,8$ \\
& Total & 97 & 100 & Modus $=22,6$ \\
& & & Min. $=12,5$ \\
& & & Maks. $=45$ \\
\hline
\end{tabular}

Sumber: Data primer tahun 2012

Tabel 4. Distribusi Responden Berdasarkan Status Kesadaran Gizi Keluarga (KGK) pada Keluarga yang Memiliki Anak Balita yang Terdaftar di Posyandu di Wilayah Kerja Puskesmas Sewon I Bantul Yogyakarta

\begin{tabular}{llll}
\hline No & Status Kesadaran Gizi Keluarga (KGK) & Jumlah & Persentase (\%) \\
\hline 1. & Belum KGK & 42 & 43,3 \\
2. & Sudah KGK & 55 & 56,7 \\
& Total & 97 & 100 \\
\hline
\end{tabular}

Sumber: Data primer tahun 2012 
Tabel 5. Distribusi Responden Berdasarkan Status Gizi Balita pada Anak Balita yang Terdaftar di Posyandu di Wilayah Kerja Puskesmas Sewon I Bantul Yogyakarta

\begin{tabular}{ccccl}
\hline No & $\begin{array}{c}\text { Status Gizi Balita } \\
(\mathrm{BB} / \mathrm{TB})\end{array}$ & Jumlah & Persentase (\%) & \multicolumn{1}{c}{ Statistik } \\
\hline 1. & Tidak Normal & 39 & 40,2 & Mean $=-0,13$ \\
2. & Normal & 58 & 59,8 & Median $=-0,56$ \\
& Total & 97 & 100 & Modus $=-2,02$ \\
& & & Min. $=-2,97$ \\
& & & Maks. $=4,94$ \\
\hline
\end{tabular}

Sumber: Data primer tahun 2012

d. Analisis Bivariat

Hasil analisis bivariat menunjukkan bahwa: 1) Ada hubungan antara asupan makanan (energi dan protein) dengan status gizi balita ( $p$ value $=0,00$ pada $\alpha=$ $0,05)$ dan kemungkinan untuk mendapatkan status gizi tidak normal dapat dilihat dari nilai RP, hasil output memperlihatkan $\mathrm{RP}=2,872(95 \% \mathrm{Cl}=2,028-4,068)$, artinya balita yang mendapatkan asupan makanan (energi) kurang, mempunyai peluang mengalami status gizi tidak normal atau salah sebesar 2,872 kali lebih besar dibandingkan dengan balita yang mendapatkan asupan makanan (energi) cukup, dan secara statistik bermakna; 2) ada hubungan antara status Kesadaran Gizi Keluarga (KGK) dengan status gizi balita ( $p$ value $=0,03$ pada $\alpha=0,05$ ) dan kemungkinan untuk mendapatkan status gizi tidak normal dapat dilihat dari nilai RP, hasil output memperlihatkan RP $=1,695(95 \% \mathrm{Cl}=1,039-2,764)$, artinya balita yang tinggal bersama dengan keluarga berstatus belum KGK memiliki peluang mengalami status gizi tidak normal atau salah sebesar 1,695 kali lebih besar dibandingkan balita yang tinggal bersama dengan keluarga berstatus sudah KGK, dan secara statistik bermakna. Hal tersebut sebagai mana tertulis pada tabel 6 .

Tabel 6. Hasil Analisis Bivariat

\begin{tabular}{|c|c|c|c|}
\hline Variabel Independent & $\begin{array}{c}\text { RP (Rasio Preva- } \\
\text { lensi) }\end{array}$ & $\begin{array}{l}\text { Confidence Interval } \\
\text { (Cl) } 95 \%\end{array}$ & $\begin{array}{l}\text { Significancy } \\
(p \text { value })\end{array}$ \\
\hline $\begin{array}{l}\text { Variabe } \\
\text { Asupan Makanan } \\
\text { (Energi dan Protein) } \\
\text { Kurang (1) }\end{array}$ & $\begin{array}{r}\mathrm{N}=07 \\
\text { pendent: Status } \mathrm{G} \\
2,872\end{array}$ & $\begin{array}{c}\text { Balita Indeks BB/TB } \\
(2,028-4,068)\end{array}$ & 0,00 \\
\hline \multicolumn{4}{|l|}{ Cukup (2) } \\
\hline \multicolumn{4}{|c|}{ Variabel Dependent: Status Gizi Balita Indeks BB/TB } \\
\hline $\begin{array}{l}\text { Status Kesadaran Gizi } \\
\text { Keluarga (KGK) } \\
\text { Belum KGK (1) }\end{array}$ & 1,695 & $(1,039-2,764)$ & 0,03 \\
\hline Sudah KGK (2) & & & \\
\hline
\end{tabular}

Sumber: Data primer tahun 2012 


\section{B. Pembahasan}

Status gizi adalah ekspresi dari keadaan keseimbangan dalam bentuk variabel tertentu atau perwujudan dari nutriture dalam bentuk variabel tertentu ${ }^{8}$. Status gizi balita sangat dipengaruhi oleh lingkungan sosial terdekat ${ }^{9}$. Penyebab langsung status gizi adalah makanan anak dan penyakit infeksi yang mungkin diderita anak. Pandangan Islam mengenai keharusan untuk menjaga kesehatan, termasuk pencegahan penyakit melalui makan makanan yang bergizi, tersirat dalam Q. S. At Tiin, 95: 04 (mengenai penciptaan manusia dalam bentuk yang sebaik-baiknya) dan Q. S. Al Maa'idah, 05: 88 (mengenai makanan yang halal lagi baik bagi manusia). Hasil penelitan yang dilakukan pada bulan Juni 2012, memperlihatkan bahwa dari 97 balita yang diteliti, terdapat 39 balita $(40,2 \%)$ termasuk dalam kriteria status gizi tidak normal atau salah dan 58 balita $(59,8 \%)$ sisanya, termasuk dalam status gizi normal. Ada bermacam-macam faktor yang dapat mempengaruhi status gizi balita. Faktor yang diduga berhubungan dengan status gizi balita dalam penelitian ini, antara lain asupan makanan dan status Kesadaran Gizi Keluarga (KGK).

\section{a. Asupan Makanan (Energi)}

Kenyataan yang terjadi dilapangan menunjukkan bahwa sebagian besar balita yang memiliki asupan makan yang cukup, terdapat pada responden dengan tingkat pendidikan minimal SLTA, pendapatan minimal UMR, dan jenis kelamin laki -laki. Berdasarkan hal tersebut di atas, maka peneliti mengasumsikan bahwa asupan makanan (energi) pada balita, dipengaruhi oleh beberapa faktor, diantaranya pendidikan responden, pendapatan responden, dan jenis kelamin balita. Hal ini menandakan bahwa pendidikan ibu sangat penting untuk menentukan pola asuh, terutama dalam pemilihan makanan untuk balitanya ${ }^{10}$, dan keterbatasan penghasilan keluarga turut menentukan mutu makanan yang disajikan, baik kualitas maupun kuantitas makanan ${ }^{11}$. Semakin tinggi tingkat pendidikan responden, maka asupan makanan (energi) yang diberikan kepada balita adalah semakin baik. Keadaan tersebut tentunya masih ditopang dengan pendapatan dari responden tersebut, semakin tinggi tingkat pendapatan responden, maka akan semakin beraneka ragam makanan yang dikonsumsi dan akan semakin baik pula nilai asupan makanan (energi) dari balitanya. Jenis kelamin juga turut mempengaruhi asupan makanan (energi) balita. Balita berjenis kelamin laki-laki lebih banyak mendapatkan asupan makanan (energi) cukup dibanding balita berjenis kelamin perempuan. Responden selalu memberikan porsi lebih untuk asupan makanan (energi) kepada balita berjenis kelamin laki-laki dibanding perempuan. Keadaan itu sendiri dinilai wajar oleh sebagian masyarakat karena masyarakat berpendapatbahwa laki-laki membutuhkan asupan yang lebih besar, sebab laki-laki lebih banyak mengeluarkan tenaga dibanding perempuan.

b. Asupan Makanan (Protein)

Kenyataan di lapangan mengenai berbagai faktor yang berperan dalam kondisi ini, tidak jauh berbeda dengan faktor yang berperan dalam asupan makanan (energi). Balita dengan asupan makanan (protein) yang cukup lebih banyak dijumpai pada responden dengan tingkat pendidikan minimal SLTA, berpenghasilan minimal sama dengan UMR, dan balita berjenis kelamin laki-laki, oleh karena itu, peneliti masih mengasumsikan bahwa asupan makanan (protein) pada balita, dipengaruhi oleh beberapa faktor, diantaranya pendidikan responden, pendapatan 
responden, dan jenis kelamin balita. Semakin tinggi tingkat pendidikan ibu, maka semakin rendah angka gizi buruk pada anak balita ${ }^{12}$. Hal tersebut secara tidak langsung menyiratkan bahwa asupan makanan dari balita tersebut membaik seiring dengan meningkatnya pendidikan ibu, karena gizi buruk terjadi saat asupan makanan dari balita berada jauh di bawah nilai standar, disamping itu, pendapatan masih tetap berpengaruh terhadap kualitas dan kuantitas makanan yang disajikan ${ }^{11}$.

\section{c. Asupan Makanan (Energi dan Protein)}

Keadaan di lapangan menunjukkan bahwa sebagian responden di wilayah tersebut memiliki kebiasaan untuk membeli satu jenis makanan pada waktu dan tempat yang bersamaan untuk konsumsi balitanya dan keadaan tersebut berlangsung hampir setiap hari, misalnya beberapa responden yang setiap sore selalu membeli bakso di satu tukang bakso yang sama untuk dikonsumsi oleh balitanya. Jenis makanan yang sama, yang dibeli pada waktu yang bersamaan, di pedagang yang sama akan memberikan asupan yang sama pada nilai energi dan protein dari makanan tersebut, untuk beberapa balita yang mengkonsumsi makanan tersebut dalam jumlah dan takaran yang juga sama, dengan demikian peneliti mengasumsikan adanya pola konsumsi yang sama pada masyarakat di wilayah kerja Puskesmas Sewon I Bantul Yogyakarta. Susunan makanan sangat dianjurkan untuk menjamin keseimbangan zat gizi, hal itu dapat tercapai dengan mengkonsumsi beraneka ragam makanan ${ }^{7}$.

\section{d. Status Kesadaran Gizi Keluarga (KGK)}

Hasil statistik univariat memperlihatkan bahwa sebanyak 55 keluarga $(56,7 \%)$ sudah termasuk dalam kriteria KGK. Keluarga dengan status sudah KGK tersebut pada umumnya dijumpai pada responden dengan kriteria pendidikan tinggi, pendapatan minimal sama dengan Upah Minimum Regional (UMR), dan jumlah anggota keluarga yang sedikit, yaitu kurang dari sama dengan 4 orang dalam satu keluarga. Pernyataan di atas menandakan bahwa pengetahuan ibu adalah penting untuk penerapan keanekaragaman makanan dalam Kesadaran Gizi Keluarga (KGK)7 dan semakin tinggi pendapatan maka, maka akan semakin baik gizi keluarga ${ }^{13}$. Jumlah anggota keluarga yang sedikit juga memberikan pengaruh terhadap status KGK. Balita yang tinggal bersama dengan keluarga dengan jumlah anggota keluarga yang sedikit, akan lebih mudah dipantau perkembangannya, disamping itu, pemenuhan keanekaragaman zat gizi pada keluarga kecil akan lebih mudah dibandingkan pada keluarga besar, terutama untuk responden dengan tingkat pendapatan yang terbatas.

e. Status Gizi Balita (BB/TB)

Perkembangan berat badan dalam keadaan normal, akan searah dengan pertumbuhan tinggi badan dengan kecepatan tertentu ${ }^{8}$. Balita yang memiliki status gizi normal, sebagian memiliki Berat Badan (BB) $\geq 11,5 \mathrm{~kg}$ dan Tinggi Badan (TB) sangat sesuai untuk meneliti status gizi saat ini karena terpengaruh secara langsung dengan makanan yang dikonsumsi sehari-hari dan status kesakitan dari balita yang merupakan faktor yang mempengaruhi status gizi secara langsung. Peneliti mengasumsikan bahwa ada factor yang mempengaruhi status gizi secara langsung. Peneliti mengasumsikan bahwa ada faktor lain yang mempengaruhi status gizi selain 
selain asupan makanan dan morbiditas balita. Faktor tersebut antara lain pendidikan orang tua (terutama ibu), pekerjaan orang tua, pendapatan orang tua, dan jumlah keluarga. Keadaan di lapangan menunjukkan bahwa balita dengan status gizi normal, lebih banyak dijumpai pada responden dengan pendidikan yang baik, dengan pekerjaan sebagai ibu rumah tangga, pendapatan lebih dari Upah Minimum Regional (UMR), dan jumlah anggota keluarga yang sedikit.

Responden dengan pendidikan yang baik, tentu mengetahui makanan apa saja yang baik dan tidak baik untuk diberikan kepada balitanya, karena seorang ibu akan menentukan pola asuh yang akan dipilihnya terutama penentuan makanan untuk balitanya10. Pekerjaan responden sebagai ibu rumah tangga tentunya akan memberikan banyak waktu bagi responden untuk menemani dan merawat balitanya, disamping itu, pendapatan $\geq$ Upah Minimum Regional (UMR) tentunya akan memberikan kesempatan kepada responden untuk dapat memberikan asupan makanan yang terbaik untuk balitanya, yang tentunya hal ini akan berpengaruh terhadap status gizi dari balitanya, terlebih lagi bila keluarga dari responden tersebut termasuk dalam kriteria keluarga kecil. Hal tersebut dikarenakan keterbatasan penghasilan turut menentukan makanan yang disajikan ${ }^{11}$. Jumlah anggota keluarga secara tidak langsung dapat berpengaruh terhadap status gizi dari balita tersebut ${ }^{14}$. Lingkungan yang kurang sehat tentunya akan membawa dampak yang kurang baik bagi kesehatan balita, meski balita itu sendiri telah dibekali dengan asupan makanan yang cukup. Balita sehat yang terlalu lama terpapar dengan balita sakit, lama-lama balita tersebut juga akan menjadi rentan dan kemudian jatuh sakit. Seseorang yang terpapar dan rentan terhadap keterpaparan tersebut maka orang tersebut akan menjadi sakit ${ }^{15}$.

f. Hubungan antara Asupan Makanan (Energi dan Protein) dengan Status Gizi Balita

Hasil analisis bivariat menunjukkan bahwa asupan makanan (energi dan protein) berhubungan dengan status gizi balita. Balita yang status gizinya normal, sebagian besar mempunyai asupan makanan yang cukup. Hal ini menandakan bahwa makanan berpengaruh secara langsung terhadap status gizi ${ }^{10}$. Peneliti mengasumsikan bahwa asupan makan balita dapat menjadi kurang dikarenakan beberapa faktor, diantaranya adalah tingkat pendidikan responden, pendapatan responden, dan jenis kelamin balita, sebagaimana telah tersebut di atas, bahwa asupan makanan yang cukup, lebih bayak ditemukan pada responden dengan pendidikan minimal SLTA, pendapatan minimal sama dengan UMR, dan balita berjenis kelamin laki-laki. Faktor-faktor tersebut merupakan faktor yang dapat mempengaruhi status gizi secara tidak langsung, karena faktor tersebut mempengaruhi asupan makan baik energi atau protein dari balita, yang kemudian barulah asupan makan tersebut mempengaruhi status gizi dari balita yang diteliti.

Status gizi adalah hasil akhir dari keseimbangan antara makanan yang masuk ke dalam tubuh (nutrition intake) dengan kebutuhan tubuh (nutrition output) akan zat gizi tersebut8. Anak yang makanannya tidak cukup baik maka daya tahan tubuhnya akan melemah dan akan mudah terserang penyakit10. Anak yang sakit maka berat badannya akan menjadi turun sehingga akan berpengaruh terhadap status gizi dari anak tersebut ${ }^{16}$. 
g. Hubungan antara Status Kesadaran Gizi Keluarga (KGK) dengan Status Gizi Balita

Hasil analisis bivariat menunjukkan bahwa status Kesadaran Gizi Keluarga (KGK) dinyatakan berhubungan dengan status gizi balita. Balita dengan status gizi normal lebih banyak ditemukan pada keluarga dengan status sudah KGK dibanding dengan keluarga dengan status belum KGK. Hal ini menandakan bahwa semakin baik status Kesadaran Gizi Keluarga (KGK) maka akan semakin baik pula status gizi dari balita yang tinggal di dalamnya ${ }^{17}$. Status Kesadaran Gizi Keluarga (KGK) termasuk penting dalam mewujudkan status gizi yang normal bagi balita. Peneliti mengasumsikan bahwa terdapat beberapa faktor yang dapat mempengaruhi status Kesadaran Gizi Keluarga (KGK) dari sebuah keluarga yang kemudian secara tidak langsung mempengaruhi status gizi dari balita yang diteliti, faktor-faktor tersebut diantaranya adalah pendidikan responden, pendapatan responden, dan jumlah keluarga responden. Status Kesadaran Gizi Keluarga (KGK) yang baik, sebagian besar terdapat pada responden dengan pendidikan minimal SLTA, pendapatan minimal sama dengan UMR, dan termasuk dalam kriteria keluarga kecil, dengan jumlah anggota keluarga kurang dari sama dengan empat orang.

\section{SIMPULAN DAN SARAN}

\section{A. Simpulan}

lain:

Kesimpulan yang dapat diperoleh dari hasil penelitian dan pembahasan, antara

a. Tingkat asupan makanan di wilayah kerja Puskesmas Sewon I, Bantul, Yogyakarta, untuk energi dan protein, keduanya termasuk dalam kriteria cukup.

b. Tingkat status Kesadaran Gizi Keluarga (KGK) di wilayah kerja Puskesmas Sewon I, Bantul, Yogyakarta sudah cukup tinggi, dimana sebagian besar dari penduduk sudah termasuk dalam kriteria sadar gizi.

c. Tingkat status gizi balita di wilayah kerja Puskesmas Sewon I, Bantul, Yogyakarta sudah cukup baik, dimana sebagian besar dari balita termasuk dalam kriteria status gizi baik atau normal.

d. Ada hubungan antara asupan makanan (energi dan protein) dengan status gizi balita di wilayah kerja Puskesmas Sewon I, Bantul, Yogyakarta.

e. Ada hubungan antara status Kesadaran Gizi Keluarga (KGK) dengan status gizi balita di wilayah kerja Puskesmas Sewon I, Bantul, Yogyakarta.

\section{B. SARAN}

a. Bagi Institusi Terkait atau Puskesmas Sewon I Bantul Yogyakarta

Pola konsumsi sama yang terjadi di masyarakat kurang memberikan dampak yang baik bagi perkembangan dan pertumbuhan balita di daerah tersebut, oleh karena itu perlu adanya penyuluhan mengenai gizi seimbang kepada masyarakat. Ibu diharapkan dapat memberikan makanan yang bervariasi kepada balitanya.

b. Bagi Peneliti Lain

Status gizi balita dipengaruhi oleh beberapa faktor, baik secara langsung maupun tidak langsung. Faktor yang secara langsung mempengaruhi status gizi balita, antara lain: makanan dan status kesakitan balita. Hasil penlitian 
memperlihatkan bahwa faktor-faktor tersebut dipengaruhi oleh faktor-faktor lain yang secara tidak langsung telah mempengaruhi status gizi balita, oleh karena itu, peneliti menyarankan untuk meneliti status gizi balita dilihat dari faktor-faktor yang mempengaruhinya secaratidak langsung, seperti pendidikan, pekerjaan, pendapatan, jumlah anggota keluarga, dan jenis kelamin balita.

\section{DAFTAR PUSTAKA}

1. Departemen Kesehatan Republik Indonesia, Profil Kesehatan Indonesia Tahun 2005, Pusat Data Kesehatan Departemen Kesehatan Republik Indonesia, Jakarta. Hal. 56. 2005.

2. Badan Penelitian dan Pengembangan Kesehatan, Riset Kesehatan Dasar (RISKESDAS) Laporan Nasional 2007, Departemen Kesehatan Republik Indonesia, Jakarta. Hal. 35-36. 2007.

3. Badan Penelitian dan Pengembangan Kesehatan, Riset Kesehatan Dasar (RISKESDAS) Laporan Nasional 2010, Departemen Kesehatan Republik Indonesia, Jakarta. Hal. 24-27, 70. 2010.

4. Dinas Kesehatan D. I. Yogyakarta, Profil Kesehatan Propinsi D. I. Yogyakarta Tahun 2008, Pusat Data Kesehatan Dinas Kesehatan Propinsi D. I. Yogyakarta, Yogyakarta. Hal. 12, 31. 2008.

5. Puskesmas Sewon 1, Profil Puskesmas Sewon I, Puskesmas Sewon I, Yogyakarta. 2011.

6. Dinas Kesehatan Kabupaten atau Kota Bantul, Profil Kesehatan Kabupaten atau Kota Bantul Tahun 2007, Dinas Kesehatan Kabupaten atau Kota Bantul, Yogyakarta. Hal. 19. 2007.

7. Simanjuntak, E., Kajian Penerapan Keluarga Sadar Gizi (Kadarzi) pada Keluarga Mampu di Keluran Mangga dan Keluarga Tidak Mampu di Simalingkar B Kecamatan Medan Tuntungan Tahun 2009, Skripsi, Fakultas Kesehatan Masyarakat, Universitas Sumatera Utara, Medan. Hal. 1, 38, 39. 2009.

8. Supariasa, I. D. N., Bakri, B., dan Fajar, I., Penilaian Status Gizi, Penerbit Buku Kedokteran EGC, Jakarta. 2002.

9. Hariyadi, D., Damanik, M. R., dan Ekayanti, I., Analisis Hubungan Penerapan Pesan Gizi Seimbang Keluarga dan Perilaku Keluarga Sadar Gizi dengan Status Gizi Balita di Propinsi Kalimantan Barat, Jurnal Gizi dan Pangan, Vol. 5 (1): Pp. 61-68. 2010.

10. Damanik, M. R., Ekayanti, I., dan Hariyadi, D., Analisis Pengaruh Pendidikan Ibu Terhadap Status Gizi Balita di Proponsi Kalimantan Barat, Jurnal Gizi dan Pangan, Vol. 5 (2): Pp. 69-77. 2010.

11. Suparyanto, Konsep Dasar Status Gizi Balita, http://status-gizi-balita/konsep-dasarstatus-gizi-balita, diambil pada tanggal 10 April 2012, Yogyakarta.

12. Khaldun, S., Z-Skor Status Gizi Balita di Proponsi Sulawesi Selatan 2007, Jurnal Sains dan Teknologi, Vol. 8, No. 2: Pp. 112-125. 2008.

13. Harniwita, Pengaruh Tingkat Pendapatan Terhadap Gizi Keluarga di Desa Buluh Cina Kecamatan Siak Hulu Kabupaten Kampar, Jurnal Penelitian, Vol. 9, No. 1: Pp. 60-68. 2008.

14. Amaral, Pedro, Hubungan antara Jumlah Anggota Keluarga dan Kebiasaan Makan dengan Status Gizi Anak Balita usia 36-59 Bulan di Desa Tirilolo Kecamatan Baucau Kota Kabupaten Baucau Timor Leste Tahun 2010, Skripsi, S-1 IImu Gizi, Stikes Ngudiwaluyo, Ungaran. 2010. 
15. Bustan, M. N., Pengantar Epidemiologi, Edisi Revisi, PT. Rineka Cipta, Jakarta. Hal. 25. 2006.

16. Nurcahyo, K. dan Briawan, D., Konsumsi Pangan Penyakit Infeksi dan Status Gizi Anak Balita Pasca Perawatan Gizi Buruk, Jurnal Gizi dan Pangan, Vol. 5 (3): Pp. 164-170. 2010.

17. Syafly, Hilma, Hubungan Perilaku Keluarga Sadar Gizi (Kadarzi) dengan Status Gizi Balita di Kota Jambi, Skripsi, Fakultas Ekologi Masyarakat, Institut Pertanian Bogor, Bogor. Hal. Iv. 2011. 